August,

\section{THE PURIFICATION OF SEWAGE ON SLATE BEDS.*}

By W. J. DIBDIN, F.I.C., F.C.S., Ето.

I $\mathrm{N}$ attempting to dispose of sewage matters without obtaining a profit from the process, the wisest plan is to utilise the forces of nature as completely as possible and to employ as many grades of life as we conveniently can.

Natural conditions of waste disposal vary so as to permit the survival of many organisms in different places. We have to select the methods of nature which exist where man can live healthily and develop his powers without inconvenience from the waste substances he produces. In selecting these conditions there are two points which can serve as a guide.

One is that the life of a running stream is preferable from the human standpoint to that of a stagnant pond. Where stagnant ponds abound man is inconvenienced by the organisms whose survival is thereby rendered possible. We must, therefore, avoid anything in the nature of stagnation or of a cesspit.

The other point is allied to the first. Heaped accumulations of waste organic matter are offensive and dangerous. Their neighbourhood is unhealthy. We must, therefore, avoid the accumulation of solid offensive refuse in bulk.

The reason for the offensive decay both of stagnant dissolved matters and heaped solids is in the non-supply of an adequate amount of oxygen to allow the preponderating development of aerobic organisms. Offensive putrefaction is the symptom of anaerobic action. That aerobic action is non-putrefactive is shown by the condition of a body of fresh water into which is discharged an amount of sewage insufficient to cause a reduction of the maintained aeration below the degree essential to aerobic life.

In the case of the Thames and London sewage, the disposal of the solids is effected by dispersal in tidal waters in the estuary, and the effluent is diluted in the Thames, which, till now, has been able to take it without offence.

Where a body of non-potable water is not available for dilution, the aerobic forces of nature can be utilized by scientific irrigation of suitable land. Here the top thin layer of soil contains the purifying agents, and was

* Read before the West of England and South Wales Branch of the Society of Medical Officers of Health on March 19th, 1908. called the "living earth" by the late Dr. Vivian Poore. When suitable land is not available, and we have to arrange artificial methods for the natural forces to do their work, the same conditions should be observed. The opportunity for the cultivation of the same quality and variety of aerobic organisms should be provided.

In view of the possibility that at some future time the Thames would be inadequate for the dilution of the London effuent, and because land was not economically available for London, I made experiments with regard to effluent filtration following the experience already obtained in the filtration of potable waters. I found that the acrobic bacteria which predominate in a fine contact bed are comparable to those common to well-aerated streams, and purify, as is well known, the dissolved substances in the same manner as when dilution in a stream is effected.

I designed the coarse contact bed to effect the inoffensive disposal of the solids, and the first beds were installed at Sutton. In many cases, after some years' use, it was found that the resulting humus and the detritus of the sewage accumulated as earthy residues in the interstices of the beds, and necessitated their cleansing in order to restore their capacity.

Further, when these beds were overworked, putrefaction ensued from mal-aeration.

Although the cost of cleansing is very low, as is doubtless well-known to you from the Manchester and Burnley reports, and does not justify the introduction of preliminary treatment in unnatural anaerobic tanks, I decided to try to obviate the choking, and consequent necessity for cleansing, of the coarse beds. I found that a bed constructed of thin layers of material, separated so as to allow a considerable water capacity, provided a skeleton for the employment of the forces at work on irrigation plots and in aerated streams. The accidental realization of the possibility of utilizing the immense amount of waste slate at the Welsh quarries enabled me to put the design into practical and economical form.

The action of the slate bed is the action of a series of irrigation surfaces superimposed instead of spread out in one plane. The effective surface is the layer of living earth produced on each slate by the action of aerobic organisms on the deposited sewage matters. The beds are fully matured when this deposit is about a quarter of an inch average in depth. 
This depth is not exceeded on the average during the year for reasons I am about to give.

The older deposit is converted as in irrigation into a mould or earth containing vast numbers of animals and bacteria. The numerous worms and protozoa are a feature of its content. The bulk is a gelatinous mass of bacteria in zoogloea form in which are mixed the cellulose fibres and grit of the sewage and other matters which are refractory or indigestible.

The gelatinous mass breaks away at the edges of the slates and is discharged with the effluent at the rate of some two grains per gallon averaged over the year, a quantity Dr. Gilbert Fowler calls a "trace." From a strong sewage, such as that of Devizes, the average deposit per filling may be taken as about onefortieth of an inch in depth. These fresh sewage solids form food for the organisms in the worked-out " earth " beneath them, and are rendered inoffensive by the digestive processes of the animal organisms, which, as is well known, attack the less stable portions first. Ultimately, the new deposit is merged in the gelatinous mass, and the residue is discharged with the effluent as described.

The presence of such organisms as worms is a guarantee that at no time can there be a preponderance of offensive anaerobic organisms. The maintenance of aeration is provided by the rest periods after the beds have been emptied after two hours standing full. During the rest period empty, the destruction of the solids continues, just as in land treatment when the liquid has drained off, leaving them exposed to the air. The maintenance of aeration during filling and resting full is provided by the air trapped under the slates.

The effluent is naturally highly charged with aerobic bacteria, and is, therefore, in a very suitable condition for further treatment on land, by dilution, or on secondary beds.

The reduction of the débris from the slate beds, as compared with the mass of sludge obtained by chemical precipitation, is shown by the following figures:-

In two and a half years, by chemical precipitation, about 8,500 tons of sludge were obtained, which was pressed to 1,700 tons of pressed cake. In the next two and a half years about fifty tons only of inoffensive earth have been collected from the effluent channel of the slate beds, and from the surface of the clinker beds.
The secondary treatment at Devizes is on fine contact beds. Unfortunately, a ferruginous clinker was used, and the subsequent oxidation and swelling of the iron into a spongy form has lowered the capacity of the beds considerably. They would be restored by re-sifting and washing.

The following analysis of clinker will show where the trouble occurs:-

\begin{tabular}{|c|c|c|c|c|c|c|}
\hline \multirow{2}{*}{\multicolumn{3}{|c|}{ Retained on $1 / 4$-inch mesh }} & \multicolumn{2}{|c|}{$\begin{array}{l}\text { No. I Bed. } \\
\text { Per cent. }\end{array}$} & & $\begin{array}{l}\text { No. } 5 \mathrm{Bed} \\
\text { Per cent. }\end{array}$ \\
\hline & & & $\ldots$ & $42 \cdot 0$ & & $11 \cdot 1$ \\
\hline , & "1/8-inch & , & $\ldots$ & 200 & & 26.2 \\
\hline \multirow{5}{*}{$\begin{array}{l}\text { Passed } \\
\text { Moisture }\end{array}$} & "1/16-ineh & , & $\ldots$ & $2 \cdot 8$ & & $14 \cdot 2$ \\
\hline & 1/32-inch & , & $\ldots$ & $0 \cdot 8$ & & 6.0 \\
\hline & 1/32-inch & $"$ & $\cdots$ & $10 \cdot 4$ & & $19 \cdot 6$ \\
\hline & $\ldots$ & $\ldots$ & & $24 \cdot 0$ & & $22 \cdot 9$ \\
\hline & & & & $10 \cdot 0$ & & $100 \cdot 0$ \\
\hline \multirow{2}{*}{\multicolumn{4}{|c|}{$\begin{array}{l}\text { Anhydrous oxide of iron in the } \\
\text { finematerial passing } 1 / 32 \text {-inch } \\
\text { mesh } \ldots \\
\text { Water of hydration and organic } \\
\text { matter in the clinker as re- } \\
\text { ceived } \quad \ldots \quad \ldots \quad \ldots\end{array}$}} & $9 \cdot 9$ & & $9 \cdot 5$ \\
\hline & & & & 4. & & $5 \cdot 6$ \\
\hline
\end{tabular}

These results show that the organic matter, after allewing for the water of hydration, is very small.

The quantity of suitable materials in these clinkers is, for No. 1 bed, equal to 75 per cent. of the volume of clinker, and in No. 2 bed equal to 62 per cent. of the volume of the clinker at present in use.

The final treatment is on land. But for the contract to send the effluent over this land, triple treatment on beds would at times be necessary for this sewage, which often contains over 400 grains of suspended matter per gallon, and in other respects is of an average strength six times that of London sewage.

The particular feature of the works to which I would draw your attention is, of course, the work done in the slate beds, and the difference between the results obtained and those from any other system for the disposal of solids.

There is no separate compartment or cultivation tank for the exclusive benefit of anaerobic bacteria. Consequently, putrefactive organisms are restricted, and cannot develop sufficiently to cause a nuisance any more than they can in a well-aerated running stream. The stagnant pond condition is entirely avoided.

The system is, in fact, a permanent adaptation of those natural processes which do not inconvenience man, and requires no renewal, because the material is permanent and the beds are self-cleansing. 


\section{DISCÜSSION.}

Mr. Wallis Stoddart stated that he was very pleased to have the opportunity of seeing the slate. beds in company with Mr. Dibdin, and to have certain points cleared up. He understood that slate beds did not represent the fullest degree of oxidation obtainable. Mr. Stoddart emphasized the importance of using non-destructible clinker.

In reply to $\mathrm{Mr}$. Waterfall, $\mathrm{Mr}$. Dibdin stated that there was no treatment of the sewage previous to its flow on to the slate beds, except by means of a grit tank.

Dr. Tubb Thomas referred to the necessity of avoiding previous treatment of the sewage, and stated that in his opinion any treatment in closed tanks was an absolute mistake-the sewage must be fresh.

The Mayor of Devizes stated that they were very satisfied with the working of the slate beds as compared with the old precipitation process. The County Council had not had occasion to complain of the condition of the brook since its introduction.

Dr. WAylen (Medical Officer of Health for Devizes) stated that the stream was very much improved since the slate beds had been introduced. He thought that the choking of the secondary filter beds was due to the softness of the filter beds, and suggested shingles. Soft beds became converted almost into mud.

Mr. Billingham (Surveyor, Devizes) stated that the cost of precipitation had been reduced from $\mathfrak{E 7 0 0}$ to $\mathfrak{E 2 0 0}$ per annum by the slate beds, and that their only trouble had been due to the use of soft material. There were no complaints now. The capacity was based on six times the dry weather flow.

Mr. DiBidin, in reply, emphasized the importance of secondary and even tertiary treatment, and that slate beds deal with solids mainly, but also secondarily, with albuminous matters in solution. If the sewage was very dilute, slate beds would give an effluent up to the standard. In Boston, with eight percolation beds, they required fifty acres, whereas if slate beds were used, twenty-three acres would do the same work. Percolation beds increased suspended solids, whilst albuminous matters were reduced thirty-five to forty per cent. by slate beds.

Aт a recent examination at a West Ham elementary school, the children were asked what a medical officer of health had to do. These are some of the answers:-

He has to see the doctors of the borough do their work.

He has to see the dustbins emptied.

He has to find out if the milkman has put chalk in the milk or the grocer sand in the pepper.

See that the factory chimneys don't pour out too much smoke.

To see that all waste matters are put on unoccupied ground.

Write to the decorators about the drains.

Look after burst water pipes.

See that everything we eat is in good condition. One child returned this striking answer: "He discovered the circulation of the blood."

\section{THE PREVENTION OF CONSUMPTION, AND THE FIGHT AGAINST TUBERCULOSIS.}

By T. Orme Dudfald, M.D.,

Medical Officer of Health, Kensington.

(From the Annual Report on the Health of the Royal Borough of Kensington, 1907.)

$\mathrm{T}^{\mathrm{H}}$ HE prevention of consumption engaged much public attention last year; especially, as we shall see later on, in Ireland, where the disease is relatively far more fatal than in England. Of the matters which occupy the thoughts of public health administrators, none exceeds this in importance, for the "great white plague;" as consumption has been well called, whilst being the cause of a vast number of deaths-forty thousand yearly in England and Wales - is both preventable and curable. A cause of untold misery to its victims, and those dependent upon them, it involves an immense drain upon the rates for the relief of the sick, the support of widows and orphans, and otherwise. The question therefore is one of national concern, and all right-thinking persons must desire that no effort should be spared to stamp out so devastating a scourge.

As regards sanatorium provisions, much has been done by private enterprise to supply the needs of well-to-do persons, able to pay, and not a little by local authorities in different parts of the country. But hitherto nothing approaching a national system for coping with a national need has been evolved. Such a system for the benefit of the chargeable poor could be created by the classification of Poor Law institutions, and the setting apart of some of them in each county as refuges for advanced, incurable cases, so dan gerous to the community, and of others, as hospitals, for the treatment of recent cases in the initial stages of the disease, when it admits of alleviation or cure. I do not know whether the adoption of this plan would necessitate an application to Parliament, or whether it may be within the competence of the Local Government Board; in any case, however, it would appear to be within their power as regards the Metropolitan District, by Section. 5 of the Metropolitan Poor Act, 1867, which enables the Board "by order [to] direct that any building for the time being in use as a workhouse be, with such alterations as the Board think fit, used for [an] asylum [i.e., for sufferers from an infectious disease or otherwise], and thenceforth that building shall be for the common use of the district accordingly." But the simpler course would be for the Board to issue an order making Section 5 applicable to the case of poor persons suffering from consumption, who would then be legally admissible to the asylums of the Metropolitan Asylums Board. To enable the Asylums Board to admit non-chargeable persons, legislation would be required.

So much premised, I propose in what follows to submit some account of the state of the "fight" against consumption as now going on in the three kingdoms with an ever-increasing intensity which presages ultimate victory to the cause of humanity.

And, first, with respect to Fngland, and as 